\title{
Curriculum Review Process at the School of Mining Engineering at the University of the Witwatersrand
}

\author{
Rudrajit Mitra*, Cuthbert Musingwini, Paskalia Neingo, Zeenath Adam \\ School of Mining Engineering, University of the Witwatersrand, Johannesburg, South Africa
}

\begin{abstract}
The School of Mining Engineering (Wits Mining) at the University of the Witwatersrand (Wits) has a long history of Mining Engineering education, being the oldest and largest on the African continent. In 2016, the School celebrated 120 years in existence and according to the recent QS University Rankings, it is recognized as one of the world's top mining engineering schools, hosting an expansive program. It also has one of the highest growth rates of any of the engineering schools or departments, having seen a consistent increase in students to its program. (1) Need for re-curriculation: With mines in South Africa going deeper as shallow Mineral Resources are depleted, the challenges facing the industry today are substantial. However, best-practice innovations and technology offer the opportunity for the design and management of hightech mines that are not only safer, but also more productive and environmentally and socially responsible, while still being economically successful. Feedback from industry experts and alumni continuously alluded to revising the existing BSc (Mining) curriculum in order to cater for the needs of an innovative and technology driven mining industry. The School hence decided to go through a comprehensive 2 day curriculum review workshop which hosted academic staff and industry experts from several engineering streams. (2) Finding: The future mining engineer should encompass skills and knowledge in 4 broad streams namely: Basics of Science and Mathematics, relevant core technical skills, operational management and a socio-economic understanding. (3) Aim: The School's new Strategic Plan and new technology driven curriculum will ensures that the Wits Mining Team can deliver Excellence in Teaching, Research and Service - in line with the Wits Vision 2022 of being "a leading research-intensive university firmly embedded in the Top 100 world universities by 2022". This paper reflects on the process that was undertaken for this review and comment on the final outcome that was attained.
\end{abstract}

Keywords: mining engineering, curriculum redesign, Industry 4.0, Wits

\section{Introduction}

The term "Industry 4.0" refers to the next development stage in the organisation of the entire value chain process in the manufacturing industry (Deloitte 2014). The first industrial revolution began in the late $18^{\text {th }}$ century with the advent of steam power and the invention of the power loom. This led to mechanization and radically changed how goods were manufactured. The late $19^{\text {th }}$ century gave rise to the second industrial revolution when electricity and assembly lines made mass production possible. The third industrial revolution was observed in the beginning of the 1970s, when advances in computing enabled the programming of machines and networks, powering automation (Deloitte 2018). Figure 1 provides an overview of the evolution of these industrial revolutions.

According to Marr (2016), Industry 4.0 introduces what has been called the "smart factory". In this system, the cyber-physical systems monitor the physical processes in the factory and make decentralized decisions. The physical systems become an Internet of Things (IoT), communicating and cooperating both with each other and with humans in real time via the wireless web.
Complex mining tasks are increasingly being handled by smart analytics software packages, while smartphones and other handheld devices have transformed the way that workers interact - not only with each other but with machines. Advances in robotics and sensor technology are also now making guided equipment much more affordable and effective. The use of tele-remote, assisted control and fully autonomous equipment is becoming increasingly widespread in the mining industry. These technologies will enable a fundamental shift in the way mining has been done in the past. There will be reduced variability in decisionmaking and more centralised automated operations that reduce variability in execution (Carter 2017). Further, according to Gorecky et al (2014), the development of Industry 4.0 will be accompanied by changing tasks and demands for the people in the factory.

From a mining perspective, the challenges facing the industry are increasing with environmental concerns becoming broadly understood, emergent technology changing the nature of work and society and resource nationalism fuelling the expectations of a better life. This is changing the roles and attributes of the mining engineer of

* Corresponding Author: Rudrajit Mitra, Email: rudrajit.mitra@wits.ac.za, phone: +27 632132866 
the future, as it is being shaped with new and emergent technology and working practices, increased stakeholder expectations around competitive economic returns and rents, and community expectations for an inclusive and sociably acceptable industry (Smith 2017).
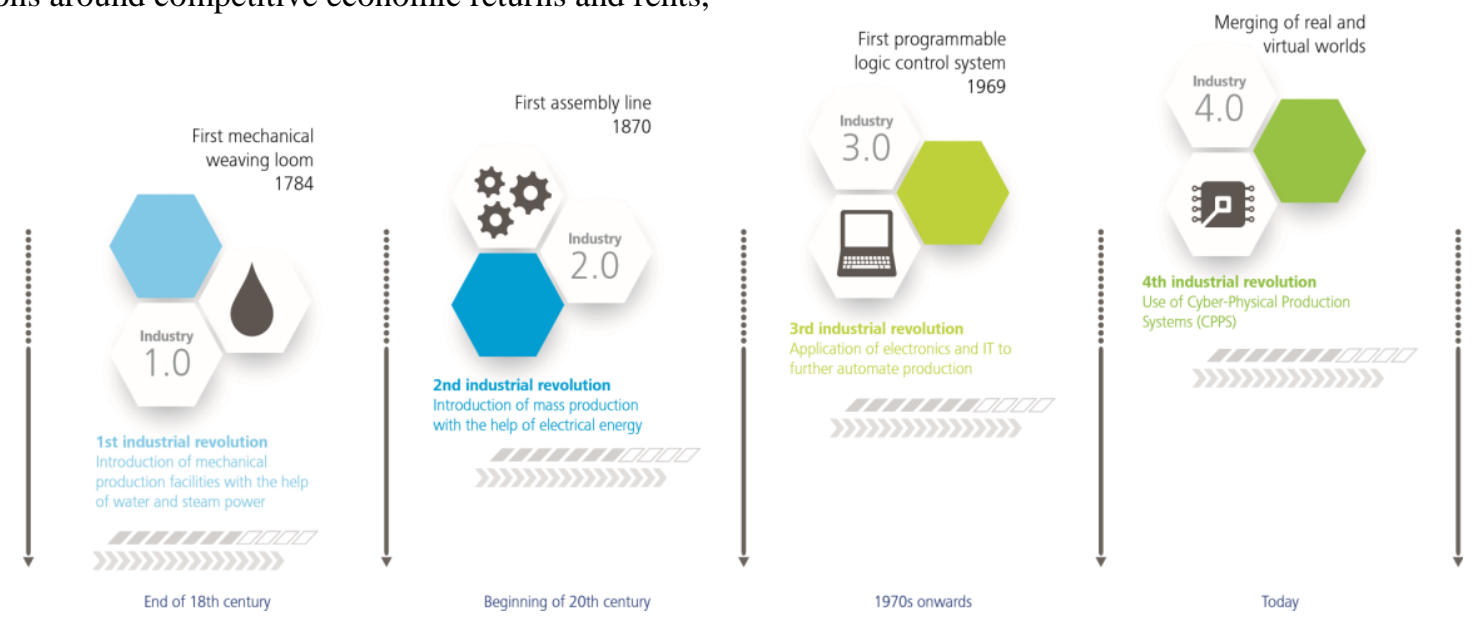

Figure 1 Evolution of Industry 4.0 (Deloitte 2014)

According to Weber-Youngman (2017), the following is how the mine of the future will look like:

(1) Remote control of most mining activities;

(2) Reduced man-machine interface risk through the use of advanced robotics and autonomous or near autonomous driverless vehicles;

(3) Virtual reality and augmented reality applications;

(4) Real time mine production monitoring and analysis through scanning and other monitoring initiatives and related real time response to the information obtained;

(5) Real time mine planning and design optimisation the digital twin concept; and

(6) Mine design holography.

In order to prepare graduates for this new industrial revolution, Universities need to play a key role in training young minds to adapt to this new industry. As part of this need, the School of Mining Engineering at the University of the Witwatersrand (Wits) identified the requirement to redefine their curriculum to address these issues.

\section{School of Mining Engineering at Wits}

The School of Mining Engineering (Wits Mining) at the University of the Witwatersrand (Wits) has a long history of Mining Engineering education, being the oldest and largest on the African continent. In 2016, the School celebrated 120 years in existence and according to the recent QS University Rankings, it is recognized as one of the world's top mining engineering schools, hosting an expansive program. It also has one of the highest growth rates of any of the engineering schools or departments, having seen a consistent increase in students to its program. It currently offers both undergraduate and postgraduate degrees.

The undergraduate program is a 4 year degree designed to provide graduates with the engineering expertise they require as mining engineers. The School has, in conjunction with the South African mining industry, developed a range/suite of postgraduate courses designed to cater for the needs of graduates, which include technical subjects for specialist skills in mining, mineral resource management and evaluation, and rock engineering, as well as management skills in evaluation techniques and fundamental principles in mineral economics. On an average, the School has approximately 600 students across the four years in the undergraduate program.

Wits Mining graduates are ready for the industry's challenges and the School of Mining Engineering at Wits is known and respected internationally for the quality of its programs and graduates. The School's new Strategic Plan and new technology driven curriculum will ensure that the Wits Mining Team can deliver Excellence in Teaching, Research and Service - in line with the Wits Vision 2022 of being "a leading research-intensive university firmly embedded in the Top 100 world universities by 2022".

With mines in South Africa going deeper as shallow mineral resources are being depleted, the challenges facing the industry today are substantial. However, best-practice innovations and technology offer the opportunity for the design and management of high-tech mines that are not only safer, but also more productive and environmentally and socially responsible, while still being economically successful.

The School has a very active Industry Advisory Council, comprising of industry experts, and one of the objectives of the Council is to make sure that the School continues to deliver top class education to the students. The School also has regular meetings with other stalwarts from the Industry. During many of these meetings, there has been a consistent request from them to look into reviewing the curriculum for the BSc (Eng) degree in Mining Engineering. Sections 3 to 6 will discuss the program that is currently being undertaken along with the process that was followed to redefine the current curriculum.

\section{Current Mining Program at Wits}

The curriculum for the BSc (Eng) in Mining Engineering is a fixed 4-year curriculum without any variants and is typical 
of most international 4-year Bachelor degree curricula in mining engineering. Entrants into the program are mainly top academic school-leaving applicants both local and international, and from time to time there are few or no entrants that come from other routes. The Mining Engineering program recently underwent an accreditation process by the Engineering Council of South Africa (ECSA) and was granted full accreditation for another 5 years until 2022. The accreditation is carried out following the Washington Accord guidelines, to which South Africa is a signatory.

The primary purpose of the degree program is to prepare graduates who are eligible to register as Candidate Engineers (CE) upon graduation and eventually register as Professional Engineers (Pr. Eng.) once they have adequately completed the necessary training and experience requirements while being employed in the mining or related industries. Upon registration as a professional engineer, the graduates are able to practice individually as competent practicing engineers. The secondary purpose of the degree program is to enable graduates to proceed into postgraduate studies through one of the research Master degree programs that have or may not have a coursework component.

Mathematical and Natural science skills are developed through Mathematics and Science courses in the first and second year curricula and include courses such as Mathematics, Physics, Chemistry, Mechanics and Geology. Engineering Science skills are developed mainly in the second year curriculum through engineering courses such as Excavation Engineering and Electrical Engineering. Design skills are developed in courses that include Mining Graphics and Design in first year, Computerized Mine Design in third year and mining methods courses that involve a mini-design project in the final year. The final year Mine Design project which, is the capstone course for the degree, examines design and synthesis skills. Information Technology skills are developed throughout the degree program in a majority of the courses. Mining Engineering skills are developed in the third and fourth year curricula through such courses as Mining Methods, Technical Valuation, Mine Ventilation and Climate Control, and Rock Mechanics and Rock Engineering. Complementary Studies are introduced through courses such as Mine Management Principles, Mine Management Techniques, Financial Valuation and the Industrial and Research Seminar courses.

The structure allows for a coherent natural progression and development of the appropriate skills and competencies required in the ECSA accreditation's 11 Exit-Level Outcomes (ELOs), as described below:

ELO 1: Problem solving;

ELO 2: Application of scientific and engineering knowledge;

ELO 3: Engineering design;

ELO 4: Investigations, experiments and data analysis;

ELO 5: Engineering methods, skills and tools, including information technology;

ELO 6: Professional and technical communication;

ELO 7: Sustainability and impact of engineering activity;
ELO 8: Individual, team and multidisciplinary working;

ELO 9: Independent learning ability;

ELO 10: Engineering professionalism; and

ELO 11: Engineering management.

Table 1 provides a list of the courses that students have

Table 1 List of courses in current undergraduate Mining Engineering program

\begin{tabular}{|c|c|}
\hline \multicolumn{2}{|l|}{ Year 1 courses } \\
\hline MINN1001A & Engineering Skills (Mining) \\
\hline MATH1014A & Mathematics I \\
\hline PHYS1014A I & Physics IE \\
\hline PHYS1015A & Mechanics \\
\hline CHEM1033A & Chemistry (Auxiliary) \\
\hline MINN1000A & Mining Graphics \& Design \\
\hline MINN1997A I & Practical Training (Mining) \\
\hline \multicolumn{2}{|c|}{ Year 2 courses } \\
\hline APPM2014A & Applied Mathematics IIA \\
\hline ELEN2000A & Electrical Engineering \\
\hline GEOL1001A & Geology 1A \\
\hline GEOL1002A & Geology IB \\
\hline MATH2012A & Mathematics II \\
\hline APPM2014A & Applied Mathematics IIA \\
\hline ELEN2000A & Electrical Engineering \\
\hline GEOL1002A & Geology IB \\
\hline MINN1996A & Practical Workshop Training (Mining) \\
\hline MINN1998A & Vacation Work I (Mining) \\
\hline \multicolumn{2}{|c|}{ Year 3 courses } \\
\hline CHMT3018A & Ore Dressing \& Extractive Metallurgy \\
\hline GEOL3028A & Ore Body Modelling \\
\hline MINN3000A & Industrial \& Research Seminars I \\
\hline MINN3001A & Mine Transportation \\
\hline MINN3002A & Mining Engineering Laboratories \\
\hline MINN3003A & Technical Valuation \\
\hline MINN3004A & Computerised Mine Design \\
\hline MINN3006A & Rock Mechanics \\
\hline MINN3011A & Mine Ventilation \& Climate Control \\
\hline MINN3012A & Mine Surveying \\
\hline MINN3013A & Mining A \\
\hline MINN3014A & $\begin{array}{l}\text { Health, Safety \& the Mining } \\
\text { Environment }\end{array}$ \\
\hline \multicolumn{2}{|c|}{ Year 4 courses } \\
\hline MINN4000A & Mine Management Principles \\
\hline MINN4001A & Mine Management Techniques \\
\hline MINN4002A & Industrial \& Research Seminars II \\
\hline MINN4003A & Mining B \\
\hline MINN4004A & Mining C \\
\hline MINN4005A & Financial Valuation \\
\hline MINN4006A & Mine Design \\
\hline MINN4007A & Project Report \\
\hline MINN4008A & Mining D \\
\hline MINN4009A & Mining E \\
\hline MINN4010A & Rock Engineering \\
\hline
\end{tabular}


to currently undertake in the 4-year undergraduate mining engineering program.

\section{Process followed to Re-define the Curriculum}

As discussed in the earlier section, there has been a consistent request to redefine the current program at the School taking into account the various aspects of Industry 4.0. Specifically, the request has been to include more innovation and future technologies into the program. The School hence decided to go through a comprehensive 2 day curriculum review workshop with input from academic staff and industry experts. Invitations were sent to various experts in the mining industry across South Africa. On the day, there was a fair representation from the industry, both from coal and metalliferous mines and also from surface and underground operations. The Dean and Assistant Dean (Undergraduate) of the Faculty of Engineering and Built Environment at Wits were also invited. Further, staff from Mechanical \& Industrial Engineering and Electrical Engineering were invited so that they can be involved in this curriculum redesign process as the future of Mining Engineering involves automation, robotics and artificial intelligence, amongst other fields. An external person from another University facilitated this process. His selection was based on his expertise and prior experience in curriculum design at other Universities.

The discussion was centered around a document that was commissioned by the School's Industry Advisory Council,-written by Smith (2017). According to Smith (2017), it is no longer appropriate to educate mining engineers in only how to design and operate mines safely and productively. The attributes and competencies of mining engineers needs to be redefined to accommodate the increasingly diverse and complex responsibilities across multiple disciplines and technologies. Furthermore, Smith (2017) indicated that there is a critical need to effectively incorporate the social license to operate, environmental and social impact assessment, regulatory and permitting constraints, risk assessment and management across the mine life cycle. A future undergraduate mining engineering curriculum requires to produce graduates with the ability to understand and operate within the holistic nature of mining engineering across the three dimensions:

(1) Core technological competencies that encompass the impact of Industry 4.0 on mining processes and people;

(2) A fundamental understanding of the skill sets, techniques and best practices across the environmental and social dimensions of the social license to operate;

(3) The capability to operate effectively in an increasingly interdisciplinary environment, especially relating to social intelligence, emotional intelligence and leadership skills.

A benchmarking exercise was done across mining engineering programs in the world and it was realised that none of the programs included the dimensions discussed above. Given that the Faculty of Engineering and Built Environment (FEBE) at Wits is underway in the process of introducing a common first year from 2019, this made sense for the School to reassess its entire program with respect to the implications of a common first year, content flow and development towards the eleven ELOs as discussed earlier.

The members present in the workshop were grouped together and each group was asked to design their own curriculum based on the discussion during the day. At the end of the day, these were collated and presented on the morning of the $2^{\text {nd }}$ day. The combined curriculum from the groups were discussed and finally, the courses were grouped in the following four classes:

(1) Fundamentals;

(2) Relevant core technical skills;

(3) Fundamental operational management knowledge;

(4) Firm understanding of the socio-economic landscape.

\section{Redefined Mining Curriculum at Wits}

The main message from the workshop was that innovation, automation, personal skills, entrepreneurship, amongst others are necessary inclusions into the program.

In order to have flow of content through the years of study, some course were either moved to different semesters or merged in order to make place for new courses/content. Some of the new courses that have been introduced into the new program include: Digital Technologies and Mine Data Analytics; Engineering Services for Mining; Mine Transportation, Automation \& Robotics; Water, Energy \& the Environment; Mine Management Principles \& Entrepreneurship; and Health, Safety \& Mining Law. The content of the other courses will also be changed taking into account Industry 4.0. Table 2 provides a summary of all the courses that will be in the new redefined curriculum.

\section{Way Forward}

Currently, the School undergraduate management team is in discussion with the Faculty, University and other Schools in the University who deliver the service courses for the School to provide the necessary information for this new curriculum to be effective from 2019. The School has received full support from the Faculty for the changes and its curriculum model is currently being used as a template for other Schools in the Engineering Faculty.

The Engineering Faculty will roll out the Common First Year from 2019, and will be followed by the introduction of the new $2^{\text {nd }}$ year curriculum in 2020 , with the new curriculum being fully phased in by 2022 .

\section{Conclusions}

The world is moving into the next development stage, termed as the $4^{\text {th }}$ industrial revolution. The mining industry, just as any other industry, is also in the process of moving into this new stage. It has been realised that in order for the industry to successfully embrace Industry 4.0, the University needs to train graduates with certain skills and attributes so that they can be easily acceptable into the industry and will be able to make a huge impact in this new revolution. 
As part of this new development, the School of Mining Engineering at Wits took a leading role, to redefine their undergraduate mining engineering curriculum after discussion with experts from the industry and academics from other streams. The new program will be rolled out from 2019, with $4^{\text {th }}$ year curriculum being first taught in 2022.

Table 2 List of courses in the new redefined Mining Engineering program (includes common first year)

\begin{tabular}{ll}
\hline Year 1 courses (Common first year) \\
\hline Semester 1 & Semester 2 \\
\hline Engineering Mathematics & Engineering Mathematics \\
1A & 1B \\
\hline Engineering Physics 1A & Engineering Physics 1B \\
\hline Engineering Analysis \& & $\begin{array}{l}\text { Engineering Analysis \& } \\
\text { Design 1A }\end{array}$ \\
\hline Introduction to the & Applied Mechanics for \\
Engineering Profession & Engineering \\
\hline $\begin{array}{ll}\text { English Literature in } \\
\text { Context I (recommended } \\
\text { elective) }\end{array}$ & Engineering Chemistry \\
\hline
\end{tabular}

\begin{tabular}{ll}
\hline Year 2 courses & \\
\hline Semester 1 & Semester 2 \\
\hline Geology IA & Geology IB \\
\hline Mathematics II & Applied Mathematics IIA \\
\hline $\begin{array}{l}\text { Introduction to } \\
\text { Underground \& Surface } \\
\text { Mining Methods }\end{array}$ & $\begin{array}{l}\text { Engineering Services for } \\
\text { Mining }\end{array}$ \\
\hline Computer Applications in & $\begin{array}{l}\text { Computer Programming in } \\
\text { Mining }\end{array}$ \\
\hline Explosives Engineering & $\begin{array}{l}\text { Mechanical Excavation of } \\
\text { Rock }\end{array}$ \\
\hline Engineering Survey & $\begin{array}{l}\text { Digital Technologies and } \\
\text { Mine Data Analytics }\end{array}$ \\
\hline $\begin{array}{l}\text { Practical Workshop } \\
\text { Training (Mining) }\end{array}$ & Professional Development \\
\hline $\begin{array}{l}\text { Computer Programming } \\
\text { Bootcamp (Mining) }\end{array}$ & \\
\hline & \\
\hline Year 3 courses & \\
\hline Semester 1 & Semester 2 \\
\hline Mine Ventilation \& & Ore Body Modelling \\
\hline Climate Control & Snderground Mining \\
Systems & Surface Mining Systems \\
\hline Mineral Resources & Computerised Mine \\
Evaluation & Design \\
\hline $\begin{array}{l}\text { Mine Transportation, } \\
\text { Automation \& Robotics }\end{array}$ & Rock Mechanics \\
\hline $\begin{array}{l}\text { Mine Surveying \& } \\
\text { Geospatial Techniques }\end{array}$ & $\begin{array}{l}\text { Water, Energy \& the } \\
\text { Environment }\end{array}$ \\
\hline & $\begin{array}{l}\text { Ore Dressing \& Extractive } \\
\text { Metallurgy }\end{array}$ \\
\hline & \\
\hline
\end{tabular}

\begin{tabular}{ll}
\hline Year $\mathbf{4}$ courses & \\
\hline Semester 1 & Semester 2 \\
\hline Mine Technical Visits & Mine Design \\
\hline Project Report & Project Report \\
\hline Rock Engineering & \\
\hline Vacation Work (Mining) & \\
\hline Mine Management & \\
Principles \& & \\
Entrepreneurship & \\
\hline Mining Optimization & \\
Techniques \& Systems & \\
\hline Health, Safety \& Mining & \\
Law & \\
\hline Financial Valuation &
\end{tabular}

\section{References}

Carter, S., 2017. "Industry 4.0 in the Mining Industry," March 13, 2017. https://www.processonline.com.au/ content/industrial-networks-buses/article/industry-4-0in-the-mining-sector- 1259053519.

Deloitte, 2014. "Industry 4.0 - Is Africa Ready for Digital Transformation." https://www2.deloitte.com/za/en/pages/manufacturing/a rticles/africa-industry-4-0.html.

Deloitte, 2018. "The Fourth Industrial Revolution Is Here Are You Ready?" https://www2.deloitte.com /insights/us/en/deloitte-review/issue-22/industry-4-0technology-manufacturing-revolution.html.

Gorecky, D, M. Schmitt, M. Loskyll and D. Zühlke. 2014. "Human-Machine-Interaction in the Industry 4.0 Era." In Proceedings of 12th IEEE International Conference on Industrial Informatics (INDIN), 289 - 294. Portp Alegre, Brazil: IEEE. DOI: 10.1109/INDIN. 2014.6945523.

Marr, B., 2016. "What Everyone Must Know about Industry 4.0," June 20, 2016. https://www.forbes.com/sites /bernardmarr/2016/06/20/what-everyone-must-knowabout-industry-4-0/\#1dd331c5795f.

Smith, G., 2017. "Mining Engineering - 2020 and Beyond." Discussion document.

Weber-Youngman, R., 2017. "Skills Required to Thrive in the 4th Industrial Revolution." presented at the 28th Society of Mining Professors Annual Meeting \& Conference, Torino, Italy, July 4. 